\title{
Penilaian Fungsi Taman Kota Sebagai Ruang Terbuka Publik di Kota Surabaya
}

\author{
Desy Dwi Saputri \\ Departemen Perencanaan Wilayah dan Kota, Fakultas Arsitektur, Desain dan Perencanaan \\ Institut Teknologi Sepuluh Nopember (ITS), Surabaya, 60111 \\ e-mail: ddsmile05@gmail.com
}

\begin{abstract}
Abstrak-Taman kota sebagai ruang terbuka publik seharusnya memiliki empat fungsi utama yaitu fungsi ekologi, fungsi sosial-budaya, fungsi ekonomi dan fungsi estetika. Kualitas sebuah taman kota dapat diketahui melalui keberhasilan fungsi taman kota tersebut. Hingga saat ini belum terdapat penilaian terukur terhadap keberhasilan fungsi taman kota terutama taman kota di Kota Surabaya. Untuk itu peneliti mengukur tingkat efektivitas fungsi taman kota sebagai ruang terbuka publik di Kota Surabaya. Penelitian ini terbagi kedalam tiga tahapan yaitu (1)mengidentifikasi fungsi taman kota berdasarkan karakteristik taman kota di Kota Surabaya dengan menggunakan metode analisa deskriptif statistik, (2)merumuskan kriteria yang menentukan fungsi taman kota sebagai ruang terbuka publik di Kota Surabaya dengan metode analisa expert judgement, (3)menilai tingkat efektivitas fungsi taman kota sebagai ruang terbuka publik di Kota Surabaya dengan metode analisa skoring. Hasil analisa menunjukkan bahwa (1)Taman Bungkul efektif untuk fungsi sosial-budaya dengan nilai efektivitas sebesar 2,5; (2)Taman Kebun Bibit Wonorejo cukup efektif untuk fungsi estetika dengan nilai efektivitas sebesar 2,4; (3)Taman Prestasi efektif untuk fungsi estetika dengan nilai efektivitas dengan nilai efektivitas sebesar 2,5; (4)Taman Flora efektif untuk fungsi estetika dengan nilai efektivitas sebesar 2,4 (5)Taman Mundu cukup efektif untuk fungsi ekonomi dengan nilai efektivitas sebesar 2,4. Semua kriteria penentuan fungsi taman kota tergolong efektif dan cukup efektif pada semua taman kota kecuali kriteria kegiatan mencari dan mengumpulkan hasil taman yang tidak efektif dengan nilai efektivitas sebesar 1,5 pada Taman Mundu.
\end{abstract}

Kata Kunci-Kota, Ruang Terbuka Hijau (RTH), Taman Kota.

\section{PENDAHULUAN}

$\mathrm{T}$ AMAN kota merupakan bagian dari ruang terbuka hijau yang berfungsi sebagai ruang terbuka publik. Berdasarkan Peraturan Menteri Dalam Negeri Nomor 1 Tahun 2007 tentang Ruang Terbuka Hijau Kawasan Perkotaan (RTKHP), jenis RTHKP meliputi taman kota. Taman kota sebagai ruang terbuka hijau (RTH) memiliki empat fungsi utama menurut Peraturan Menteri Pekerjaan Umum Nomor 05/PRT/M/2008 tentang Penyediaan dan Pemanfaatan Ruang Terbuka Hijau di Kawasan Perkotaan. Fungsi tersebut antara lain fungsi ekologis, fungsi sosial dan budaya, fungsi ekonomi serta fungsi estetika.

Untuk menjaga fungsi tersebut maka ditetapkan proporsi penyediaan RTH pada wilayah perkotaan. Dalam UndangUndang Nomor 26 Tahun 2007 tentang Penataan Ruang, disebutkan bahwa perencanaan tata ruang wilayah kota harus memuat rencana penyediaan dan pemanfaatan ruang terbuka hijau yang luas minimalnya sebesar $30 \%$ dari luas wilayah kota. Selain itu, berdasarkan Peraturan Menteri Pekerjaan Umum Nomor 05/PRT/M/2008 tentang Penyediaan dan Pemanfaatan Ruang Terbuka Hijau di Kawasan Perkotaan, penyediaan RTH berdasarkan luas wilayah di perkotaan adalah sebesar 30\% yang terdiri dai $20 \% \mathrm{RTH}$ publik dan $10 \% \mathrm{RTH}$ non publik.

Kota Surabaya telah memenuhi proporsi penyediaan ruang terbuka hijau sesuai dengan peraturan yang telah ditetapkan. Luas RTH publik jenis taman dan jalur hijau di Kota Surabaya mencapai $1.647,71$ hektar atau 20,04\% dari total luas RTH publik yang ada di Kota Surabaya [1]. Selain itu, Kota Surabaya telah melakukan pengembangan RTH secara massif sejak tahun 2002 dengan upaya meningkatkan kualitas dan kuantitas RTH bersama masyarakat. Salah satunya adalah revitalisasi lahan milik pemerintah kota yang dialihfungsikan menjadi SPBU untuk dikembalikan fungsinya menjadi RTH pada tahun 2010 [2].

Dengan Proporsi luas RTH perkotaan yang telah terpenuhi dan upaya pemerintah Kota Surabaya dalam meningkatkan kuantitas dan kualitas ruang terbuka, sudah seharusnya RTH tersebut memberikan manfaat kepada masyarakat perkotaan sesuai dengan fungsinya. Ruang terbuka publik yang baik dapat memberikan banyak manfaat bagi suatu kawasan dan manusia yang hidup didalamnya [3]. Manfaat suatu ruang terbuka publik berupa taman kota dapat dilihat melalui keberhasilan fungsi taman kota tersebut.

Hingga saat ini telah dilakukan beberapa penelitian terkait fungsi taman kota di Kota Surabaya. Penelitian tersebut antara lain terkait diferensiasi dan redefinisi ruang terbuka publik kota melalui pemaknaan jiwa tempat dengan studi kasus pada Taman Bungkul Surabaya [4]. Pada penelitian tersebut dijelaskan bahwa Taman Bungkul sebagai ruang terbuka publik kota mengalami pergeseran fungsi dari ide awal saat dibangun dahulu dengan fenomena pemanfaatan dan pemaknaan ruang tersebut oleh masyarakat. Salah satunya adalah pemanfaatan tempat yang jauh dari kaidah dan etika ketimuran yang mengakibatkan rusaknya keindahan taman. Masalah tersebut merupakan masalah klasik yang terjadi pada taman-taman kota atau ruang publik lain yang belum mampu diselesaikan pemerintah kota atau stakeholder terkait. Sehingga perlu dilakukan penilaian fungsi taman kota yang ada saat ini.

Berdasarkan permasalahan tersebut, peneliti mengukur 
keberhasilan taman kota melalui tingkat efektivitas fungsi taman kota di Kota Surabaya. Hal tersebut penting untuk dilakukan agar manfaat yang dihasilkan suatu taman kota tetap terjaga sesuai dengan fungsi taman kota yang seharusnya. Keberhasilan fungsi taman kota yang dinilai nantinya dapat digunakan sebagai acuan dalam pengembangan taman kota agar lebih optimal dan mampu memenuhi kebutuhan masyarakat akan ruang terbuka publik dalam menunjang segala aktivitas warga kotanya.

\section{METODE PENELITIAN}

\section{A. Metode Pengumpulan Data}

Data yang digunakan pada peneilitian ini adalah data primer yang diperoleh melalui pengamatan langsung terhadap kondisi eksisting taman kota di Kota Surabaya dan wawancara serta penyebaran kuisioner kepada Expert atau pakar dan para pengguna taman yang terdiri atas pihak pemerintah, pihak masyarakat dan pihak swasta. Sedangkan data sekunder diperoleh dari dokumen instansi terkait yaitu Bappeko Surabaya dan DKRTH Kota Surabaya (Dinas Kebersihan dan Ruang Terbuka Hijau Kota Surabaya).

\section{B. Metode Analisa}

Metode analisis yang digunakan dalam mencapai tujuan terdiri atas empat tahapan yaitu (1)mengidentifikasi fungsi taman kota di Kota Surabaya berdasarkan karakteristik taman kota di Kota Surabaya, (2)merumuskan kriteria yang menentukan fungsi taman kota sebagai ruang terbuka publik di Kota Surabaya, (3)menilai tingkat efektivitas fungsi taman kota sebagai ruang terbuka publik di Kota Surabaya. Berikut merupakan penjelasan masing-masing tahapan metode analisa yang dilakukan pada penelitian ini.

1) Mengidentifikasi fungsi taman kota di Kota Surabaya berdasarkan karakteristik taman kota di Kota Surabaya

Analisis ini dilakukan dengan dua langkah. Langkah pertama yaitu mengetahui karakteristik taman kota di Kota Surabaya. Perihal yang diamati untuk mengetahui karakteristik taman kota di Kota Surabaya adalah sebagai berikut:

a.Luas taman kota dalam ukuran hektar

b.Kemudahan pengguna dalam mengakses taman kota dari ketersediaan transportasi umum dan kondisi jalan

c.Bentuk taman kota dilihat dari ketersediaan ruang terbuka hijau dan fasilitas rekreasi serta fasilitas olahraga

d.Sifat taman kota berdasarkan karakteristik pengguna taman kota dan biaya akses masuk taman kota

e.Pihak penyedia taman kota

f.Fasilitas yang tersedia pad ataman kota

Langkah kedua yaitu merumuskan fungsi taman kota di Kota Surabaya dengan membandingkan karakteristik taman kota terhadap tinjauan pustaka yang terlah dirumuskan. Output atau keluaran yang dihasilkan adalah gambaran fungsi taman kota di Kota Surabaya yang dijelaskan dalam bentuk tabel dan deskripsi. Kemudian, fungsi-fungsi taman kota tersebut digunakan untuk menentukan beberapa taman kota di Kota Surabaya yang ditetapkan sebagai obyek analisa pada tahap selanjutnya.

2) Merumuskan kriteria yang menentukan fungsi taman kota sebagai ruang terbuka publik di Kota Surabaya

Analisis ini menggunakan teknik analisa expert judgement dengan menggunakan skala likert. Skala likert sering digunakan untuk kuisioner yang mengungkap sikap dan pendapat seseorang terhadap suatu fenomena [6]. Skala likert digunakan untuk mengukur persepsi responden terkait tingkat pengaruh variabel yang telah ditentukan terhadap kriteria yang menentukan fungsi taman kota sebagai ruang terbuka publik di Kota Surabaya.

Teknik analisa expert judgement pada tahap ini dilakukan dengan perhitungan validitas isi-koefisien aiken's V, validitas isi-koefisien CVR dan validitas isi-koefisien CVI. Perhitungan validitas isi-koefisien aiken's $\mathrm{V}$ dilakukan dengan rumus sebagai berikut:

$$
\begin{aligned}
& \text { Keterangan : } \\
& \text { Lo }=\text { Angka penilaian validitas yang } \\
& V=\sum s /[n(c-1)] \quad \mathrm{C}=\begin{array}{l}
\text { terendah } \\
\text { Angka penilaian validitas yang } \\
\text { tertinggi }
\end{array} \\
& S=r-l o \quad \mathrm{R}=\text { Angka yang diberikan oleh penilai } \\
& \mathrm{N}=\text { Jumlah ahli yang menjadi penilai }
\end{aligned}
$$

Validitas isi-koefisien Aiken's V digunakan untuk menghitung content-validity coeficient yang didasarkan pada hasil penilaian dari panel ahli sebanyak $n$ orang terhadap suatu aitem dari segi sejauh mana aitem mewakili konstrak yang diukur [5]. Sedangkan, Validitas CVR dan CVI dilakukan untuk menentukan apakah setiap item dalam skala sudah sesuai atau relevan dengan konstraknya, menghitung presentase item yang dianggap relevan oleh setiap pakar dan kemudian mengambil rata-rata nilai presentase yang diberikan oleh pakar [5]. Berikut merupakan rumus perhitungan validitas isi CVR dan CVI:

$$
\begin{array}{cc}
C V R=\frac{N e-N / 2}{N / 2} & \text { Keterangan : } \\
\mathrm{Ne}= & \text { Jumlah validator } \\
& \text { yang memberikan } \\
\text { nilai }
\end{array}
$$

Hasil analisa pada tahap ini berupa deskriptif kuantitatif dari hasil perhitungan validitas isi yang dilakukan. Berikut merupakan interpretasi hasil perhitungan validitas isi yang dilakukan :

Tabel 1.

Interpretasi Hasil Perhitungan Validitas Isi

\begin{tabular}{ccl}
\hline \hline Koefisien Validitas Isi & Hasil Perhitungan & \multicolumn{1}{c}{ Keterangan } \\
\hline CVR & $\geq 0,3$ & Validitas baik \\
CVI & $\geq 0,7$ & Validitas baik \\
Aiken's V & $<0,4$ & Validitas rendah \\
& $0,4-0,8$ & Validitas sedang \\
& $>0,8$ & Validitas tinggi \\
\hline Sumber : Heri Retnawati (2016) [8] dan Hendryadi (2017) [5]
\end{tabular}

3) Menilai tingkat efektivitas fungsi taman kota sebagai ruang terbuka publik di Kota Surabaya

Analisis ini menggunakan teknik analisa skoring dengan menggunakan rating scale. Teknik analisa ini dilakukan dengan bantuan software Excel. Analisa skoring adalah 
JURNAL PENATAAN RUANG Vol. 13, No. 2, (2018) ISSN: 2716-179X (1907-4972 Print)

analisis yang menggunakan angka dengan batasan nilai pada skoring yang sudah ditentukan terlebih dahulu [7]. Skala penilaian (rating scale) serupa dengan lembar observasi (checklist) [6].

Dalam melakukan analisa skoring pada tahap ini terdapat beberapa langkah yang dilakukan. Langkah pertama adalah menentukan kategorisasi jenjang dengan menentukan data statistik secara deskriptif berupa skor tertinggi, skor terendah dan interval pada skala penilaian yang digunakan. Hasil dari langkah ini berupa skala kategorisasi penilaian pada masingmasing variabel kriteria dan pada setiap indikator fungsi atau aspek yang telah ditentukan. Kategori penilaian yang akan dihasilkan sejumlah 3 (tiga) kategori yaitu

Tabel 2.

Rumus Kategorisasi Jenjang Nilai Efektivitas Fungsi Taman Kota Di Kota Surabaya

\begin{tabular}{ccl}
\hline \hline Kelompok Kategori & Rumus Pehitungan & \multicolumn{1}{c}{ Keterangan } \\
\hline Kategori 1 & $\mathrm{X}<\left(\mu-\left(\mathrm{p}^{*} \sigma\right)\right)$ & $\begin{array}{l}\text { Kategori kurang baik } \\
\text { (tidak efektif) }\end{array}$ \\
Kategori 2 & $\left(\mu-\left(\mathrm{p}^{*} \sigma\right)\right) \leq \mathrm{X}<$ & $\begin{array}{l}\text { Kategori baik (cukup } \\
\left(\mu+\left(\mathrm{p}^{*} \sigma\right)\right)\end{array}$ \\
efektif) \\
Kategori 3 & $\left(\mu+\left(\mathrm{p}^{*} \sigma\right)\right) \leq \mathrm{X}$ & $\begin{array}{l}\text { Kategori sangat baik } \\
\text { (efektif) }\end{array}$ \\
\hline
\end{tabular}

Sumber: Hasil Sintesa Pustaka, 2018

Langkah kedua adalah menghitung jumlah skor nilai efektivitas pada setiap variabel yang kemudian dikategorikan sesuai dengan skala kategorisasi yang didapatkan pada langkah pertama. Perhitungan skor pada setiap variabel dilakukan dengan rumus berikut.

$$
Z p=\frac{\sum \text { skor penilaian }}{\sum \text { penilai }} \quad \begin{aligned}
& \text { Keterangan : } \\
& \begin{array}{l}
\text { Nilai Efektivitas fungsi } \\
\text { taman kota pada setiap } \\
\text { variabel }
\end{array}
\end{aligned}
$$

Lalu, langkah ketiga yang dilakukan yaitu menghitung jumlah skor nilai efektivitas pada setiap indikator fungsi yang telah ditentukan. Perhitungan skor pada setiap indikator dilakukan dengan rumus berikut.

$$
\begin{aligned}
& Z k a=\frac{\sum Z \text { p pada indikator } A}{\sum \text { variabel (butir } A \text { ) }} \quad \begin{array}{ll}
\text { Keterangan : } & \begin{array}{l}
\text { Nilai efektivitas } \\
\text { pada indikator A } \\
\text { (indikator fungsi }
\end{array}
\end{array} \\
& \text { sosial-budaya) } \\
& Z k b=\frac{\sum Z \text { p pada indikator } B}{\sum \text { variabel (butir } B \text { ) }} \quad \text { Zkb }=\begin{array}{l}
\begin{array}{l}
\text { Nilai efektivitas } \\
\text { pada indikator } B \\
\text { (indikator fungsi }
\end{array}
\end{array} \\
& \text { estetika) } \\
& Z k c=\frac{\sum Z \text { p pada indikator } C}{\sum \text { variabel }(\text { butir } C)} \quad \text { Zkc }=\quad \begin{array}{l}
\text { Nilai efektivitas } \\
\text { pada indikator } C \\
\text { (indikator fungsi } \\
\text { ekonomi) }
\end{array}
\end{aligned}
$$

Hasil perhitungan skor pada setiap indikator yang diperoleh berdasarkan tabel diatas kemudian dikategorikan sesuai dengan skala kategorisasi yang telah dihitung sebelumnya.

\section{HASIL DAN DISKUSI}

\section{A. Identifikasi fungsi taman kota berdasarkan karakteristik} taman kota di Kota Surabaya

\section{1) Identifikasi karakteristik taman kota di Kota Surabaya}

\begin{tabular}{|c|c|c|}
\hline Taman Kota & Alamat & $\begin{array}{l}\text { Luas } \\
(\mathrm{Ha})\end{array}$ \\
\hline Taman Flora & Jl. Raya Manyar No.80 A & 3,381 \\
\hline Taman Bungkul & Jl. Taman Bungkul & 1,452 \\
\hline Taman Prestasi & J1. Ketabang Kali No.6 & 1,530 \\
\hline $\begin{array}{l}\text { Taman Kebun Bibit } \\
\text { Wonorejo }\end{array}$ & J1. Kendal Sari Blok RK No.70 & 8,753 \\
\hline Taman Apsari & Jl. Taman Apsari & 0,530 \\
\hline Taman Ekspresi & J1. Genteng Kali No. 67 & 0,602 \\
\hline Taman Mundu & Jl. Mundu & 0.650 \\
\hline Taman BMX & Jl. Embong Kaliasin & 0,397 \\
\hline $\begin{array}{l}\text { Taman Jayengrono/Taman } \\
\text { Sejarah }\end{array}$ & Jl. Rajawali, Krembangan Selatan & 0,523 \\
\hline Taman Kunang-Kunang & Jl. Penjaringan Timur & 0,692 \\
\hline Taman Dolog/Pelangi & $\begin{array}{l}\text { Jl. Frontage Ahmad Yani } \\
\text { Siwalankerto No.138 }\end{array}$ & 0,554 \\
\hline Taman Ronggolawe & Jl. Joyoboyo & 0,394 \\
\hline Taman Keputih & $\begin{array}{l}\text { J1. Keputih Tegal Timur II No. } \\
249\end{array}$ & 8,449 \\
\hline Taman Lansia & J1. Raya Gubeng-J1.Biliton & 0,152 \\
\hline Taman Paliatif & J1. Kesumba & 0,124 \\
\hline Taman Teratai & J1. Teratai No.4 & 0,406 \\
\hline Taman Korea & J1. Dr. Soetomo No. 67 & 0,471 \\
\hline
\end{tabular}

Observasi untuk mendapatkan input data dalam analisis ini dilakukan terhadap 17 taman kota di Kota Surabaya. Berikut merupakan taman kota di Kota Surabaya yang diamati.

Tabel 3.

Taman Kota Di Kota Surabaya

Berdasarkan informasi diatas, lokasi setiap taman kota di Kota Surabaya dapat dilihat pada gambar berikut.

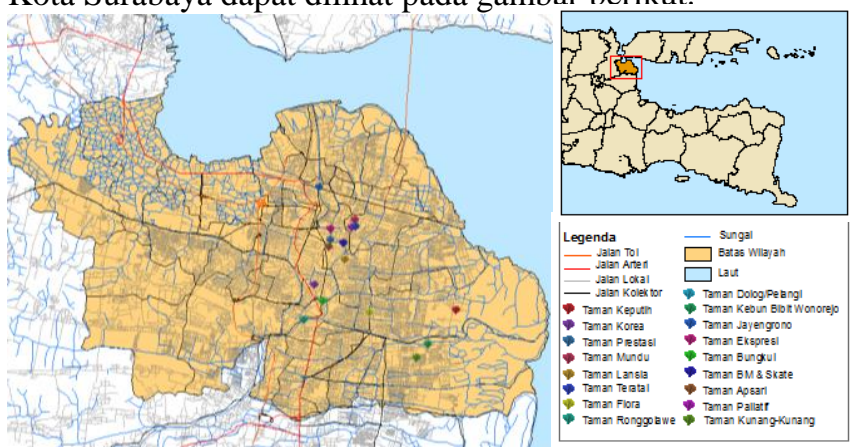

Gambar 1. Peta Taman Kota Di Kota Surabaya

Hasil observasi menunjukkan bahwa taman-taman tersebut memiliki aksesibilitas yang baik dilalui oleh transportasi umum dan memiliki kondisi jalan yang baik pula. Selain itu, semua taman kota diatas disediakan dan dikelola oleh pemerintah Kota Surabaya untuk seluruh lapisan masyarakat. Berikut merupakan kondisi eksisting beberapa taman kota di Kota Surabaya. 
JURNAL PENATAAN RUANG Vol. 13, No. 2, (2018) ISSN: 2716-179X (1907-4972 Print)

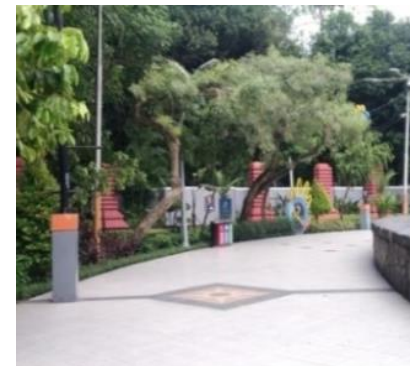

(a) Taman Bungkul

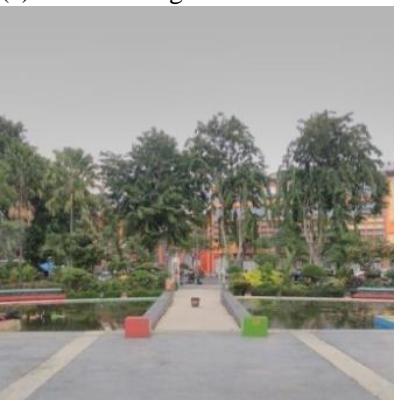

(c) Taman Mundu

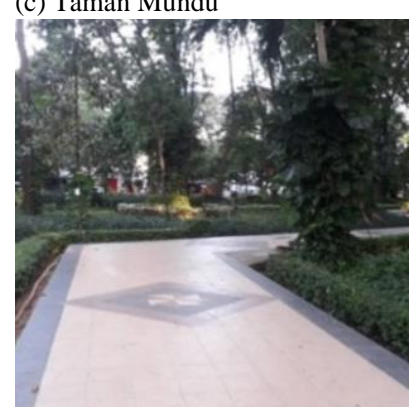

(e) Taman Flora

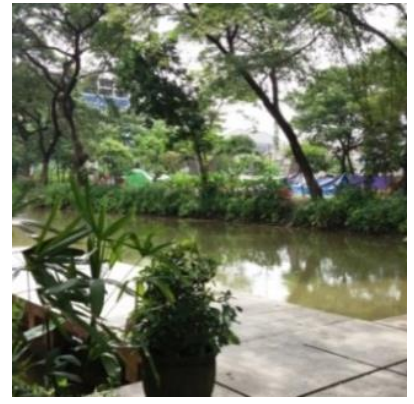

(b) Taman Kebun Bibit Wonorejo

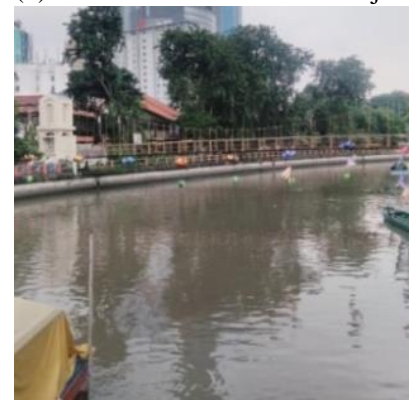

(d) Taman Prestasi

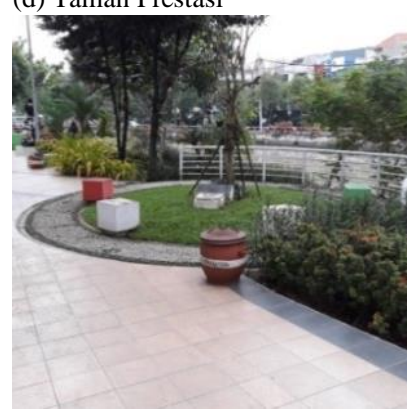

(f) Taman Ekspresi

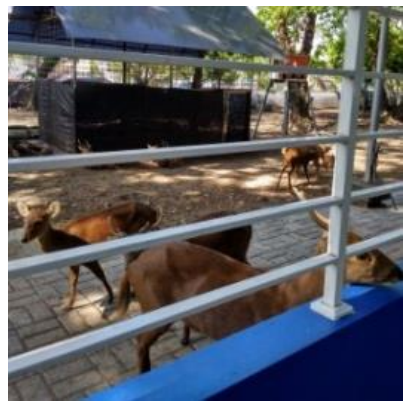

(e) Fasilitas Kebun Binatang Mini pada Taman Flora

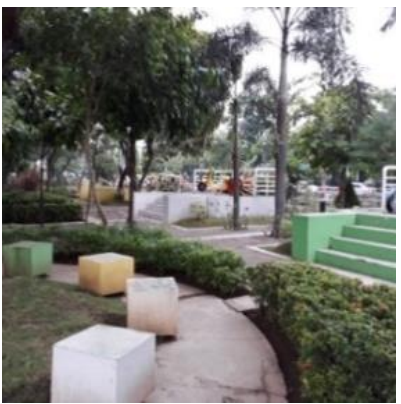

(f) Fasilitas Bangku Taman pada Taman Ekspresi

Gambar 3. Kondisi Eksisting Fasilitas Beberapa Taman Kota Di Kota Surabaya

\section{2) Perumusan fungsi taman kota di Kota Surabaya}

Berdasarkan literatur dan karakteristik taman kota di Kota Surabaya saat ini, dapat dirumuskan fungsi taman kota di Kota Surabaya sebagai berikut:

Tabel 4

Fungsi Taman Kota Di Kota Surabaya

\begin{tabular}{lc}
\hline \multicolumn{1}{c}{ Taman Kota } & Fungsi \\
\hline Taman Flora & Estetika \\
Taman Bungkul & Sosial-Budaya \\
Taman Prestasi & Estetika \\
Taman Kebun Bibit Wonorejo & Estetika \\
Taman Apsari & Sosial-Budaya \\
Taman Ekspresi & Estetika \\
Taman Mundu & Ekonomi \\
Taman BMX & Sosial-Budaya \\
Taman Jayengrono & Estetika \\
Taman Kunang-Kunang & Estetika \\
Taman Dolog/Taman Pelangi & Estetika \\
Taman Ronggolawe & Sosial-Budaya \\
Taman Keputih & Estetika \\
Taman Lansia & Sosial-Budaya \\
Taman Paliatif & Sosial-Budaya \\
Taman Teratai & Estetika \\
Taman Korea & Estetika \\
\hline
\end{tabular}

Berdasarkan hasl analisa, diketahui bahwa taman kota yang memiliki fungsi sosial-budaya dengan intensitas tinggi di Kota Surabaya adalah Taman Bungkul, Taman Apsari, Taman BMX, Taman Ronggolawe, Taman Lansia dan Taman Paliatif. Kemudian, taman kota yang memiliki fungsi estetika dengan intensitas tinggi di Kota Surabaya adalah Taman Flora, Taman Prestasi, Taman Kebun Bibit Wonorejo, Taman Ekspresi, Taman Jayengrono, Taman Kunang-Kunang, Taman Dolog/Taman Pelangi, Taman Keputih, Taman Teratai dan Taman Korea. Sedangkan, taman kota yang memiliki fungsi ekonomi dengan intensitas tinggi adalah Taman Mundu.

Berdasarkan hasil wawancara dengan ahli atau expert yang menjadi responden pada tahap ini, didapatkan bahwa terdapat 5 (lima) taman yang menjadi konsentrasi pengembangan taman kota di Kota Surabaya pada saat ini. Taman tersebut yaitu Taman Bungkul, Taman Kebun Bibit Wonorejo, Taman Flora, Taman Prestasi dan Taman Mundu. Dengan mempertimbangkan hal tersebut, maka kelima taman yang menjadi konsentrasi pengembangan taman kota di Kota Surabaya digunakan sebagai obyek penelitian ini Selain itu,

(c) Fasilitas Air Mancur pada Taman Mundu (d) Fasilitas Perahu pada Taman

Prestasi (b) Fasilitas Danau pad

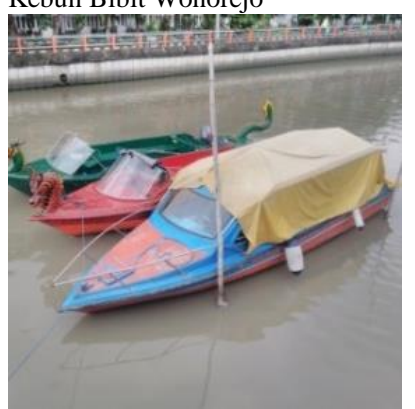


JURNAL PENATAAN RUANG Vol. 13, No. 2, (2018) ISSN: 2716-179X (1907-4972 Print)

taman kota tersebut mewakili taman kota yang memiliki fungsi sosial-budaya, fungsi estetika dan fungsi ekonomi taman kota di Kota Surabaya. Sehingga Taman Bungkul, Taman Kebun Bibit Wonorejo, Taman Flora, Taman Prestasi dan Taman Mundu ditetapkan sebagai obyek penelitian yang akan dianalisa pada tahap selanjutnya. Berikut merupakan lokasi taman kota di Kota Surabaya.

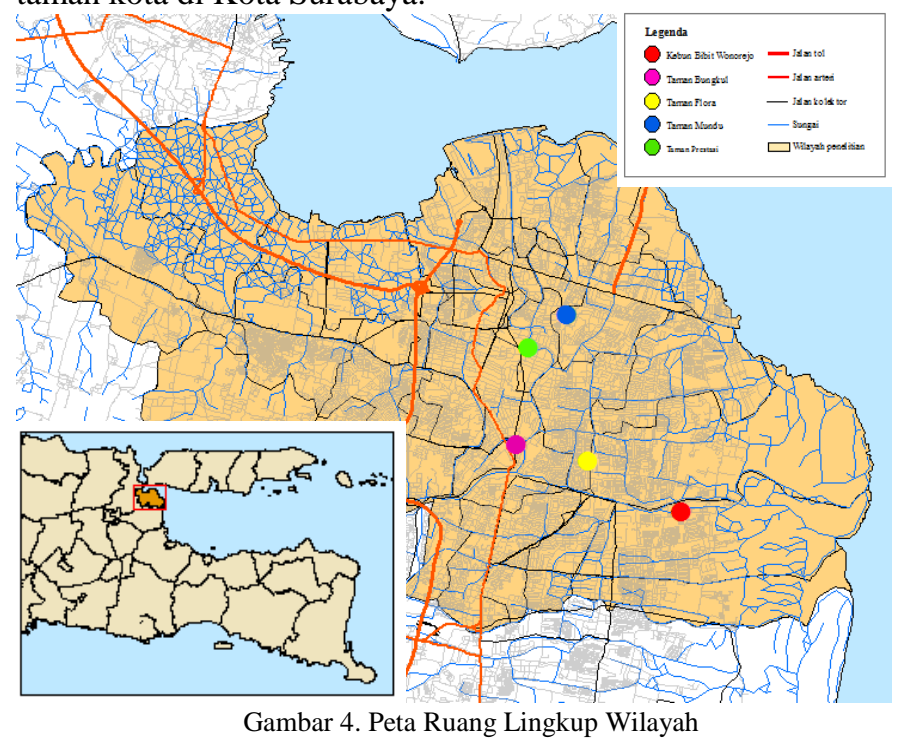

B. Perumusan kriteria yang menentukan fungsi taman kota sebagai ruang terbuka publik di Kota Surabaya

Dalam perumusan kriteria, digunakan analisa expert judgement dengan skala likert rentang 1-5 yang menunjukkan kriteria sangat berpengaruh hingga kriteria sangat tidak berpengaruh terhadap perumusan kriteria ini. Berikut merupakan indikator dan variabel yang dirumuskan sebagai kriteria yang menentukan fungsi taman kota sebagai ruang terbuka publik di Kota Surbaya.

Tabel 5.

Indikator Dan Variabel Penelitian

\begin{tabular}{clc}
\hline \hline Indikator & \multicolumn{1}{c}{ Variabel } & Kode \\
\hline & Kegiatan interaksi sosial & A1 \\
& Sarana penunjang kegiatan interaksi sosial & A2 \\
& Kegiatan rekreasi aktif olahraga dan non olahraga & A3 \\
& Sarana penunjang rekreasi aktif olahraga dan non & A4 \\
Fungsi & olahraga & A5 \\
Sosial- & Kegiatan bermain yang aman & A6 \\
Budaya & Sarana penunjang kegiatan bermain yang aman & A7 \\
& Kegiatan penelitian, pembelajaran dan pelatihan & A8 \\
& Sarana penunjang kegiatan penelitian, & A9 \\
\hline \multirow{5}{*}{ Fungsi } & pembelajaran dan pelatihan & B1 \\
& Penanda pada taman & B2 \\
& Kondisi desain elemen taman & B3 \\
Estetika & Kondisi kenyamanan taman & Bo \\
& Kondisi keamanan lingkungan & B5 \\
& Kondisi prasarana taman & B6 \\
& Kondisi pencapaian atau akses taman & B7 \\
& Kondisi area parkir & B8 \\
\hline Fungsi & Kegiatan mencari dan mengumpulkan hasil taman & C1 \\
Ekonomi & Kegiatan interaksi ekonomi barang maupun jasa & C2 \\
\hline
\end{tabular}

Pengkodean variabel tersebut selalu digunakan pada tahap analisa selanjutnya. Berdasarkan pengkodean variabel diatas, analisa penentuan kriteria dilakukan dengan menggunakan bantuan software Excel. Berikut merupakan hasil analisa expert judgement melalui perhitungan koefisien validitas isi aiken's $\mathrm{V}$.

Tabel 6.

Hasil Perhitungan Validitas Isi-Koefisien Aiken'V

\begin{tabular}{cccc}
\hline \hline Butir & $\begin{array}{c}\text { Koefisien } \\
\text { Aiken's V Hitung }\end{array}$ & $\begin{array}{c}\text { Koefisien Aiken's } \\
\text { V Standar }\end{array}$ & Keterangan \\
\hline A1 & 0,938 & 0,4 & Validitas Tinggi \\
A2 & 0,875 & 0,4 & Validitas Tinggi \\
A3 & 0,688 & 0,4 & Validitas Sedang \\
A4 & 0,688 & 0,4 & Validitas Sedang \\
A5 & 0,906 & 0,4 & Validitas Tinggi \\
A6 & 0,844 & 0,4 & Validitas Tinggi \\
A7 & 0,781 & 0,4 & Validitas Sedang \\
A8 & 0,750 & 0,4 & Validitas Sedang \\
A9 & 0,875 & 0,4 & Validitas Tinggi \\
\hline B1 & 0,906 & 0,4 & Validitas Tinggi \\
B2 & 0,969 & 0,4 & Validitas Tinggi \\
B3 & 0,781 & 0,4 & Validitas Sedang \\
B4 & 0,875 & 0,4 & Validitas Sedang \\
B5 & 0,938 & 0,4 & Validitas Tinggi \\
B6 & 0,938 & 0,4 & Validitas Tinggi \\
B7 & 0,938 & 0,4 & Validitas Tinggi \\
B8 & 0,875 & 0,4 & Validitas Tinggi \\
\hline C1 & 0,719 & 0,4 & Validitas Sedang \\
C2 & 0,750 & 0,4 & Validitas Sedang \\
\hline
\end{tabular}

Sumber: Hasil Analisis, 2018

Melalui tabel diatas, dapat diketahui bahwa sebgaian besar variabel penelitian yang telah disusun memiliki tingkat validitas yang tinggi dengan rentang nilai koefisien aiken's V lebih dari 0,8. Namun, variabel pada indikator fungsi ekonomi seluruhnya termasuk ke dalam kategori variabel yang memiliki tingkat validitas yang sedang dengan rentang nilai koefisien aiken's V antara 0,4 hingga 0,8. Sedangkan sebagian besar variabel pada indikator fungsi sosial-budaya dan indikator fungsi estetika termasuk kedalam kategori variabel yang memiliki tingkat validitas tinggi. Sehingga berdasarkan perhitungan validitas isi-koefisien aiken's V, semua variabel dapat dirumuskan sebagai kriteria yang menentukan fungsi taman kota sebagai ruang terbuka publik di Kota Surabaya. Kemudian, analisa expert judgement juga dilakukan dengan menghitung validitas isi koefisien CVR (content validity ratio) dan validiyas isi koefisien CVI (content validity index). Berikut merupakan hasil analisa expert judgement dengan perhitungan validitas isi koefisien CVR dan CVI.

Tabel 7.

Hasil Perhitungan Validitas Isi-Koefisien CVR (content validity ratio)

\begin{tabular}{cccc}
\hline \hline Butir & $\begin{array}{c}\text { Koefisien CVR } \\
\text { Hitung }\end{array}$ & $\begin{array}{c}\text { Koefisien CVR } \\
\text { Standar }\end{array}$ & Keterangan \\
\hline A1 & 1 & 0,3 & Valid \\
A2 & 1 & 0,3 & Valid \\
A3 & 1 & 0,3 & Valid \\
A4 & 1 & 0,3 & Valid \\
A5 & 1 & 0,3 & Valid \\
A6 & 1 & 0,3 & Valid \\
A7 & 1 & 0,3 & Valid \\
A8 & 1 & 0,3 & Valid \\
A9 & 1 & 0,3 & Valid \\
\hline
\end{tabular}


JURNAL PENATAAN RUANG Vol. 13, No. 2, (2018) ISSN: 2716-179X (1907-4972 Print)

\begin{tabular}{lcll}
\hline B1 & 1 & 0,3 & Valid \\
B2 & 1 & 0,3 & Valid \\
B3 & 1 & 0,3 & Valid \\
B4 & 1 & 0,3 & Valid \\
B5 & 1 & 0,3 & Valid \\
B6 & 1 & 0,3 & Valid \\
B7 & 1 & 0,3 & Valid \\
B8 & 1 & 0,3 & Valid \\
\hline C1 & 0,75 & 0,3 & Valid \\
C2 & 1 & 0,3 & Valid \\
\hline
\end{tabular}

Tabel 8.

Hasil PerhitunganValiditas Isi-Koefisien CVI (content validity index)

\begin{tabular}{cccc}
\hline \hline Butir & $\begin{array}{c}\text { Koefisien CVI } \\
\text { Hitung }\end{array}$ & Koefisien CVI Standar & Keterangan \\
\hline A1 & 1 & 0,780 & Valid \\
A2 & 1 & 0,780 & Valid \\
A3 & 1 & 0,780 & Valid \\
A4 & 1 & 0,780 & Valid \\
A5 & 1 & 0,780 & Valid \\
A6 & 1 & 0,780 & Valid \\
A7 & 1 & 0,780 & Valid \\
A8 & 1 & 0,780 & Valid \\
A9 & 1 & 0,780 & Valid \\
\hline B1 & 1 & 0,780 & Valid \\
B2 & 1 & 0,780 & Valid \\
B3 & 1 & 0,780 & Valid \\
B4 & 1 & 0,780 & Valid \\
B5 & 1 & 0,780 & Valid \\
B6 & 1 & 0,780 & Valid \\
B7 & 1 & 0,780 & Valid \\
B8 & 1 & 0,780 & Valid \\
\hline C1 & 0,875 & 0,780 & Valid \\
C2 & 1 & 0,780 & Valid \\
\hline
\end{tabular}

Berdasarkan hasil analisa perhitungan validitas isi-koefisien CVR dan validitas isi-koefisien CVI, dapat diketahui bahwa semua variabel terbukti valid. Hal tersebut menunjukkan bahwa kesepakatan expert yang menjadi penilai pada analisa ini menyetujui bahwa variabel yang telah disusun merupakan variabel yang dapat menunjukkan kriteria fungsi taman kota di Kota Surabaya. Variabel yang telah disusun seluruhnya memiliki nilai validitas mutlak yaitu sebesar 1 kecuali variabel C1 (kegiatan mencari dan mengumpulkan hasil taman). Variabel $\mathrm{C} 1$ menjadi satu-satunya variabel yang tidak memiliki nilai validitas mutlak karena terdapat satu expert yang tidak menyetujui apabila variabel $\mathrm{C} 1$ menjadi kriteria yang menentukan fungsi taman kota sebgaai ruang terbuka publik di Kota Surabaya. Sehingga validitas isi-koefisien CVR pada variabel $\mathrm{C} 1$ sebesar 0,75 dan validitas isi-koefisien CVI pada variabel $\mathrm{C} 2$ sebesar 0,875 .

Dengan membandingkan hasil perhitungan ketiga validitas isi tersebut, maka dapat disimpulkan bahwa semua variabel yang telah disusun tersebut memiliki validitas isi yang baik. Validitas isi yang baik menunjukkan bahwa semua itemitem yang telah dirumuskan dapat menjawab apa yang ingin diukur. Sehingga variabel yang ada dapat ditetapkan sebagai kriteria yang menentukan fungsi taman kota sebgaai ruang terbuka publik di Kota Surabaya.

\section{Penilaian tingkat efektivitas fungsi taman kota sebagai ruang terbuka publik di Kota Surabaya}

1) Penentuan kategorisasi jenjang tingkat efektivitas fungsi taman kota sebagai ruang terbuka publik di Kota Surabaya

Kategorisasi jenjang diawali dengan penentuan data statistik secara deskriptif berupa rentang minimum, rentang maksimum, luas jarak sebaran, mean teoritis dan deviasi standar. Berdasarkan skala penilaian yang digunakan untuk menilai tingkat efektivitas fungsi taman kota, maka didapatkan nilai data statistik sebagai berikut.

$$
\begin{array}{lll}
\mathrm{H}=3 & \mathrm{H}= & \begin{array}{l}
\text { Skor tertinggi yang diberikan oleh } \\
\text { penilai }
\end{array} \\
\mathrm{L}=1 & \mathrm{~L}=\begin{array}{l}
\text { Skor terendah yang diberikan oleh } \\
\text { penilai }
\end{array} \\
\mathrm{n}=3 & \mathrm{n}=\begin{array}{l}
\text { Jumlah rentang kategori tingkat } \\
\text { efektivitas yang ditentukan }
\end{array} \\
\mathrm{x}=3^{*} 13=39 & \mathrm{x}=\begin{array}{l}
\text { Nilai tiap kriteria penilaian yang } \\
\text { didapatkan dari perkalian skor } \\
\text { dengan frekuensi nilai yang keluar }
\end{array} \\
\mathrm{I}=\frac{H-L}{\mathrm{n}}=0,7 & \mathrm{I} & \begin{array}{l}
\text { Interval } \\
\text { Intal }
\end{array}
\end{array}
$$

Melalui data statistik seperti tabel diatas, maka didapatkan skala kategorisasi tingkat efektivitas fungsi taman kota yang terbagi menjadi tiga rentang kategori sebagai berikut.

Tabel 9.

\begin{tabular}{|c|c|c|c|c|}
\hline Variabel & $\begin{array}{l}\text { Nilai Ideal } \\
\text { Efektivitas }\end{array}$ & $\begin{array}{l}\text { Nilai Hitung } \\
\text { Efektivitas }\end{array}$ & $\begin{array}{l}\text { Rentang } \\
\text { Kategori }\end{array}$ & $\begin{array}{c}\text { Tingkat } \\
\text { Efektivitas }\end{array}$ \\
\hline $\mathrm{A} 1$ & 3,0 & 2,8 & $>2,4-3$ & Efektif \\
\hline A2 & 3,0 & 2,6 & $>2,4-3$ & Efektif \\
\hline A3 & 3,0 & 2,9 & $>2,4-3$ & Efektif \\
\hline A4 & 3,0 & 2,6 & $>2,4-3$ & Efektif \\
\hline A5 & 3,0 & 2,4 & $>1,7-2,4$ & Cukup Efektif \\
\hline A6 & 3,0 & 2,4 & $>1,7-2,4$ & Cukup Efektif \\
\hline A7 & 3,0 & 2,2 & $>1,7-2,4$ & Cukup Efektif \\
\hline A8 & 3,0 & 2,1 & $>1,7-2,4$ & Cukup Efektif \\
\hline A9 & 3,0 & 2,6 & $>2,4-3$ & Efektif \\
\hline $\begin{array}{c}\text { Indikator } \\
\text { Fungsi } \\
\text { Sosial- } \\
\text { Budaya }\end{array}$ & 3,0 & 2,5 & $>2,4-3$ & Efektif \\
\hline $\begin{array}{l}\text { Hasil } \\
\text { tingkat }\end{array}$ & ing & $n$ & va pe & ian terhadap \\
\hline
\end{tabular}

Skala Kategorisasi Tingkat Efektivitas Fungsi Taman Kota Sebagai Ruang

\begin{tabular}{cc}
\multicolumn{2}{c}{ Terbuka Publik di Kota Surabaya } \\
\hline \hline TINGKAT EFEKTIVITAS & RENTANG KATEGORI \\
\hline Efektif & $>2,4-3$ \\
Cukup Efektif & $>1,7-2,4$ \\
Tidak Efeketif & $1-1,7$ \\
\hline
\end{tabular}

2) Perhitungan tingkat efektivitas fungsi sosial-budaya Taman Bungkul sebagai ruang terbuka publik di Kota Surabaya

Analisa skoring dilakukan untuk menilai tingkat efektivitas fungai sosial-budaya Taman Bungkul dengan bantuan software excel menggunakan data hasil kuisioner sebagai input data. Berikut merupakan hasil perhitungan skoring nilai efektivitas fungsi sosial-budaya Taman Bungkul.

Tabel 10.

Hasil Perhitungan Skoring Nilai Efektivitas dan Kategori Tingkat Efektivitas Fungsi Sosial-Budaya Taman Bungkul 
yaitu sebanyak 5 (lima) variabel. Sedangkan, varibael lain tergolong cukup efektif sebanyak 4 (empat) variabel. Variabel yang tergolong efektif yaitu variabel kegiatan interaksi sosial, sarana penunjang kegiatan interaksi sosial, kegiatan rekreasi aktif olahraga dan non olahraga, sarana penunjang kegiatan aktif olahraga dan non olahraga. Kemudian, variabel yang tergolong cukup efektif yaitu variabel kegiatan bermain yang aman; sarana penunjang kegatan bermain yang aman; kegiatan penelitian, pembelajaran dan pelatihan; sarana penunjang kegiatan penelitian, pembelajaran dan pelatihan.

Melalui tabel hasil analisa diatas, diketahui bahwa variabel yang memiliki nilai efektivitas fungsi sosial-budaya paling tinggi adalah variabel kegiatan rekreasi aktif olahraga dan non olahraga dengan nilai efektivitas fungsi sosial-budaya sebesar 2,9. Sedangkan, variabel yang memiliki tingkat efektivitas paling rendah adalah variabel sarana penunjang kegiatan penelitian, pembelajaran dan pelatihan dengan nilai efektivitas fungsi sosial-budaya sebesar 2,1

\section{3) Perhitungan tingkat efektivitas fungsi estetika pada Taman} Kebun Bibit Wonorejo, Taman Flora dan Taman Prestasi sebagai ruang terbuka publik di Kota Surabaya

Analisa skoring dilakukan untuk menilai tingkat efektivitas fungai estetika pada Taman Kebun Bibit Wonorejo, Taman Flora dan Taman Prestasi dengan bantuan software excel menggunakan data hasil kuisioner sebagai input data. Berikut merupakan hasil perhitungan skoring nilai efektivitas fungsi estetika pada Taman Kebun Bibit Wonorejo, Taman Flora dan Taman Prestasi.

Tabel 11.

Hasil Perhitungan Skoring Nilai Efektivitas dan Kategori Tingkat Efektivitas Fungsi Sosial-Budaya Taman Bungkul

\begin{tabular}{ccccc}
\hline \hline & \multicolumn{5}{c}{ Nungsi Sosial-Budaya Taman Bungkul } \\
\cline { 3 - 5 } Variabel & Nilai Ideal & \multicolumn{3}{c}{ Nilai Hitung Efektivitas } \\
& Efektivitas & $\begin{array}{c}\text { Taman } \\
\text { Bibit } \\
\text { Wonorejo }\end{array}$ & $\begin{array}{c}\text { Taman } \\
\text { Prestasi }\end{array}$ & Taman Flora \\
\hline B1 & 3,0 & 2,5 & 2,7 & 2,6 \\
B2 & 3,0 & 2,3 & 2,7 & 2,5 \\
B3 & 3,0 & 2,3 & 2,2 & 2,3 \\
B4 & 3,0 & 2,4 & 2,2 & 2,2 \\
B5 & 3,0 & 2,5 & 2,5 & 2,5 \\
B6 & 3,0 & 2,5 & 2,5 & 2,4 \\
B7 & 3,0 & 2,4 & 2,5 & 2,5 \\
B8 & 3,0 & 2,4 & 2,4 & 2,3 \\
\hline \multicolumn{2}{c}{ Indikator Fungsi } & 2,4 & 2,5 & 2,4 \\
\multicolumn{2}{c}{ Ekonomi } & & &
\end{tabular}

Tabel 12.

Kategori Tingkat Efektivitas Fungsi Estetika Pada Taman Kebun Bibit Wonorejo, Taman Prestasi dan Taman Flora Di Kota Surabaya KATEGORI TINGKAT EFEKTIVITAS

\begin{tabular}{|c|c|c|c|}
\hline VARIABEL & $\begin{array}{c}\text { Taman Kebun Bibit } \\
\text { Wonorejo }\end{array}$ & Taman Prestasi & Taman Flora \\
\hline B1 & Efektif & Efektif & Efektif \\
\hline B2 & Cukup efektif & Efektif & Efektif \\
\hline B3 & Cukup efektif & Cukup efektif & Cukup efektif \\
\hline B4 & Cukup efektif & Cukup efektif & Cukup efektif \\
\hline B5 & Efektif & Efektif & Efektif \\
\hline B6 & Efektif & Efektif & Cukup efektif \\
\hline B7 & Cukup efektif & Efektif & Efektif \\
\hline
\end{tabular}

\begin{tabular}{cccc}
\hline \hline B8 & Cukup efektif & Cukup efektif & Cukup efektif \\
\hline Indikator & & & \\
Fungsi & Cukup efektif & Efektif & Cukup efektif \\
Estetika & & & \\
\hline
\end{tabular}

Tabel diatas menunjukkan bahwa tingkat efektivitas fungsi estetika dengan nilai paling tinggi berada pada Taman Prestasi dengan nilai sebesar 2,5 yang tergolong efektif. Sedangkan Taman Kebun Bibit Wonorejo dan Taman Flora memiliki tingkat efektivitas fungsi estetika yang tergolong cukup efektif dengan nilai sebesar 2,4. Kemudian, Taman Prestasi memiliki nilai efektivitas yang paling tinggi dengan nilai sebesar 2,7 yang tergolong efektif pada variabel kondisi desain elemen taman dan kondisi kenyamanan taman. Sedangkan Taman Kebun Bibit Wonorejo adalah taman yang memiliki tingkat efektivitas yang paling rendah pada kedua variabel tersebut. Lalu, variabel kondisi pos jaga dengan nilai efektivitas yang tinggi berada pada Taman Kebun Bibit Wonorejo dan Taman Flora dengan nilai efektivitas sebesar 2,3 yang tergolong cukup efektif. Selain itu, Taman Kebun Bibit Wonorejo juga memiliki nilai efektivitas yang paling tinggi pada variabel kondisi keamanan lingkungan dengan nilai efektivitas sebesar 2,4. Sedangkan Taman Flora memiliki nilai efektivitas yang paling rendah pada variabel kondisi keamanan lingkungan dengan nilai efektivitas sebesar 2,2 yang tergolong cukup efektif.

Kemudian, nilai efektivitas pada variabel kondisi kebersihan taman memiliki nilai yang sama pada semua taman sebesar 2,5 yang tergolong efektif. Taman Kebun Bibit Wonorejo dan Taman Prestasi memiliki nilai efektivitas yang paling tinggi pada variabel kondisi prasarana taman dengan nilai efektivitas sebesar 2,5 yang tergolong efektif dan kondisi area parkir dengan nilai efektivitas sebesar 2,4 yang tergolong cukup efektif. Sehingga Taman Flora memiliki nilai efektivitas paling rendah pada variabel kondisi prasarana taman dan kondisi area parkir dengan nilai efektivitas maising-masing sebesar 2,4 dan 2,3 yang tergolong cukup efektif. Kemudian, variabel kondisi pencapaian taman atau akses taman paling tinggi dengan nilai efektivitas sebesar 2,5 yang tergolong efetktif berada pada Taman Prestasi dan Taman Flora.

4) Perhitungan tingkat efektivitas fungsi ekonomi Taman Mundu sebagai ruang terbuka publik di Kota Surabaya

Analisa skoring dilakukan untuk menilai tingkat efektivitas fungai ekonomi Taman Mundu dengan bantuan software excel menggunakan data hasil kuisioner sebagai input data. Berikut merupakan hasil perhitungan skoring nilai efektivitas fungsi ekonomi Taman Mundu..

$$
\text { Tabel } 13 .
$$

Hasil Perhitungan Skoring Nilai Efektivitas dan Kategori Tingkat Efektivitas Fungsi Ekonomi Taman Mundu

\begin{tabular}{ccccc}
\hline \hline Variabel & $\begin{array}{c}\text { Nilai Ideal } \\
\text { Efektivitas }\end{array}$ & $\begin{array}{c}\text { Nilai Hitung } \\
\text { Efektivitas }\end{array}$ & $\begin{array}{c}\text { Rentang } \\
\text { Kategori }\end{array}$ & $\begin{array}{c}\text { Tingkat } \\
\text { Efektivitas }\end{array}$ \\
\hline $\mathrm{C} 1$ & 3,0 & 1,5 & $1-1,7$ & Tidak Efektif \\
C2 & 3,0 & 2,4 & $>1,7-2,4$ & Efektif \\
\hline Indikator & & & & Cukup Efektif \\
Fungsi & 3,0 & 2,0 & $>1,7-2,4$ & \\
Ekonomi & & & & \\
\hline
\end{tabular}


JURNAL PENATAAN RUANG Vol. 13, No. 2, (2018) ISSN: 2716-179X (1907-4972 Print)

Berdasarkan tabel diatas, dapat diketahui bahwa penilaian terhadap efektivitas fungsi ekonomi Taman Mundu sebagai ruang terbuka publik secara keseluruhan tergolong cukup efektif dengan nilai efektivitas sebesar 2,0. Variabel yang tergolong cukup efektif dengan nilai efektivitas 2,4 adalah variabel kegiatan interaksi ekonomi barang maupun jasa. Sedangkan, variabel kegiatan mencari dan mengumpulkan hasil taman memiliki tingkat efetivitas yang tergolong tidak efektif dengan nilai efektivitas sebesar 1,5.

\section{KESIMPULAN}

Berdasarkan analisa yang dilakukan, diketahui bahwa tingkat efektivitas fungsi sosial-budaya pada Taman Bungkul sebagai ruang terbuka publik tergolong efektif dengan nilai efektivitas sebesar 2,5. Kemudian, tingkat efektivitas fungsi estetika pada Taman Kebun Bibit Wonorejo dan Taman Flora sebagai ruang terbuka publik termasuk cukup efektif dengan nilai efektivitas sebesar 2,4. Sedangkan, penilaian tingkat efektivitas fungsi estetika pada Taman Prestasi sebagai ruang terbuka publik tergolong efektif dengan nilai efektivitas sebesar 2,5. Lalu, tingkat efektivitas fungsi ekonomi pada Taman Mundu sebagai ruang terbuka publik tergolong cukup efektif dengan nilai efektivitas sebesar 2,0.Semua kriteria yang menjadi variabel penelitian memiliki tingkat efektivitas yang tergolong efektif dan cukup efektif pada semua taman kota kecuali kriteria kegiatan mencari dan mengumpulkan hasil taman yang tergolong tidak efektif pada Taman Mundu yang memiliki fungsi ekonomi taman kota di Kota Surabaya.

\section{DAFTAR PUSTAKA}

[1] Ernawati, R. (2015), Optimalisasi Fungsi Ekologis Ruang Terbuka Hijau Publik Di Kota Surabaya, EMARA-Indonesia Journal of Architecture, Vol 1 No 2.

[2] Kharismawan, R., dan Mahendra, A.A. (2012), Kajian Kualitas TamanTaman Kota Eks-Lahan SPBU Di Surabaya Dilihat Dari Perspektif Pengguna, Seminar Nasional CITIES 2012.

[3] Putri, A. N., dan Nurini (2014), Hubungan Tingkat Ketertarikan Masyarakat Untuk Berkunjung Dengan Kualitas Taman Di Taman Menteri SUPENO, Jurnal Teknik PWK, Vol 3 No 4.

[4] Sulistyo, B. W. (2012), Diferensiasi dan Redifinisi Ruang Terbuka Publik Kota Melalui Pemaknaan Jiwa Tempat (Spirit Of Place), Jurnal IPTEK, Vol 16 No 1.

[5] Hendryadi (2017), Validitas Isi: Tahap Awal Pengembangan Kuisioner, Jurnal Riset Manajemen Dan Bisnis (JRMB) Fakultas Ekonomi UNIAT, Vol 2 No 2.

[6] Mulyatiningaih, E. (2011), Riset Terapan Bidang Pindidikan Dan Teknik, Cetakan 1, Eds: A. Nuryanto, dan Sutopo, UNY Press, Yogyakarta.

[7] Iswara, R., Astuti, W., dan Putri, R. A. (2017), Kesesuaian Fungsi Taman Kota Dalam Mendukung Konsep Kota Layak Huni Di Surakarta, Arsitektura, Vol 15 No 1.

[8] Retnawati, H. (2016), Analisis Kuantitatif Instrumen Penelitian (Panduan Peneliti, Mahasiswa, Dan Psikometrian), Cetakan Pertama, Pratama Publishing, Yogyakarta. 